\title{
Diego Belmonte Fernández, Organizar, Administrar, RECORDAR. EL Libro Blanco Y EL Libro de Dotaciones de la CATEDRaL DE SEVILLA, Sevilla, Editorial Universidad de Sevilla, 2019, 316 PÁGS. ISBN: 978-84-472-2873-7.
}

\author{
Maria Cristina Cunha
} Universidade do Porto

A obra em epígrafe resulta da Tese de Doutoramento defendida pelo Autor em 2016 na Universidade de Sevilha no ramo de História, embora não inclua (como acontece na versão original) a transcrição dos dois códices (hoje conhecidos como Libro Blanco e Libro de Dotaciones, existentes no Arquivo da Catedral de Sevilha) que lhe serviram de base. Contudo, apesar de esta tarefa de técnica paleográfica irrepreensível corresponder a um enorme trabalho despendido por Diego Belmonte que nunca é demais salientar, o estudo que faz sobre as duas fontes é muito mais abrangente. Assim, não obstante esse corte ao trabalho original, ditado certamente por razões editoriais, a investigação efectuada mantém todo o seu interesse e pertinência, e o livro em análise constitui uma mais-valia para o conhecimento de uma época (a Idade Média), de uma instituição (a catedral de Sevilha, incluindo o seu arquivo) e dos homens que estiveram ligados à escrita relativa à administração do seu património.

O livro segue uma estrutura "clássica": após a Introdução, e antes das páginas apresentadas "a modo de conclusión", o texto foi dividido em duas partes, não numeradas e não identificadas como tal, de dimensão semelhante. Na primeira, encontramos 4 pontos que se estendem por 100 páginas, dedicadas aos aspectos materiais e ao conteúdo formal dos dois livros que constituem as fontes principais do estudo (como se disse, o Libro Blanco e o Libro de Dotaciones), pelo que são apresentados os aspectos codicológicos e paleográficos dos códices e se tenta a sua classificação tipológica. A segunda parte tem como objecto de análise os contextos de elaboração e a utilização dos livros, temas que são explanados em três pontos com várias subdivisões. Finalmente, e após um conjunto de 35 ilustrações que visam dar ao leitor uma ideia mais concreta dos dois códices, seguem-se 2 anexos: o primeiro inclui um índice dos 84 documentos, ordenados cronologicamente, que serviram de base ao projecto escriturário do Autor; no anexo II, são apresentados pequenos recortes de gravuras que elucidam sobre a escrita das várias mãos não identificadas que participaram na elaboração de ambos os 
livros sobre os quais o estudo se debruça. O livro de Diego Belmonte termina com uma extensa lista bibliográfica, onde não faltam os autores clássicos, bem como as mais recentes abordagens aos vários temas patentes na obra. Pena é que esta bibliografia não tenha sido dividida de acordo com a tipologia das obras: assim, são "misturados" títulos de autores do sec. XVII a XIX (ex: Gabriel de Aranda ou a famosa compilação dos Monumenta Germaniae Historica - que foram utilizados como fontes documentais) com títulos de autores actuais, cuja obra indiscutivelmente inspirou e esclareceu Diego Belmonte. Também não nos parece positiva a inclusão conjunta de títulos referentes aos chamados auxiliares de investigação (ex. Commission Internationale de Diplomatique - "Normes internationales pour l'édition des documents médévaux") e de estudos diversos de dimensão variada.

Embora os códices que servem de base ao presente estudo fossem há muito conhecidos dos historiadores que se dedicaram à história de Sevilha e da sua catedral, ou que por motivo das suas investigações passaram pelo Arquivo desta, não tinham sido ainda objecto de estudo conjunto. A análise dos livros, em múltiplas perspectivas que englobam disciplinas como a Paleografia, a Codicologia e a Diplomática, insere-se em correntes de investigação que, desde finais do século passado, se dedicam ao estudo dos cartulários e que mostram à saciedade que os códices medievos podem ser muito mais do que meros Kopialbucher.

A pertinência do livro de Diego Belmonte reside no facto de se ter concentrado no binómio forma-função das referidas fontes documentais, atentando assim não só nos códices enquanto objectos culturais, mas também nos seus produtores. De facto, partindo da análise da materialidade e do conteúdo formal dos dois códices hispalenses, o Autor começou por fazer a sua contextualização histórica e institucional, a fim de responder a duas questões chave: o que motivou a sua elaboração e o que pretendia a catedral de Sevilha com a realização destes livros.

Ao longo do texto, Diego Belmonte prova claramente que os dois códices constituem duas faces de um mesmo instrumento destinado a saber não só quais os rendimentos de que dispunha a catedral no inicio do séc. XV, mas também como resolver o problema da traslação das sepulturas e celebração dos ofícios a que a igreja hispalense estava obrigada. Neste sentido, e porque se trata de objectos que auxiliam a gestão, o controle do património e, simultaneamente, suportes de uma memória que se pretende conservar, os dois livros, mais do que cartulários no sentido habitual do termo, devem ser enquadrados no largo conjunto das escritas cinzentas. Pretendendo entender a génese destes indispensáveis instrumentos, o Autor procurou, e identificou, os antecedentes livrários e os documentos em que se basearam.

Após uma breve descrição codicológica, o estudo prossegue com a identificação das mãos responsáveis pela escrita dos livros, tarefa dificultada pelo facto de ambos terem tido um uso prolongado. Mas precisamente como o Autor assinala, foi esta circunstância que tornou possível seguir a evolução da escrita gótica da Baixa Idade Média e inícios da época Moderna, num contexto e espaço específicos. $\mathrm{O}$ enorme número de intervenientes 
nos códices, seja com intervenções pontuais seja com registos mais completos, tornou praticamente impossível identificar claramente todas as mãos. Contudo, foi possível dividi-las em três grandes grupos (manos principales, manos secundarias e otras manos) de acordo com critérios que são devidamente apontados pelo Autor. Foi a análise minuciosa das características gráficas, identificando não só as mãos dos escribas que iniciaram os livros, como daqueles que os foram "actualizando", que permitiu a Diego Belmonte aperceber-se dos vários níveis gráficos patentes como também identificar as várias fases da tradição textual.

Na segunda parte do livro, Diego Belmonte discorre sobre a dimensão intertextual dos códices, ou seja, sobre os contextos da sua produção e utilização, como referimos mais acima. Desde logo procurou evidenciar o papel do prior Diego Martínez (cujo protagonismo fica imediatamente patente na ilustração da capa do volume que agora se analisa) que foi o responsável por verificar e registar todos os elementos escritos pertinentes para a catedral num momento delicado como era o da realização de obras de fundo na catedral. $\mathrm{O}$ estudo do perfil deste personagem surge, assim, como essencial para perceber não só a escolha da sua pessoa por parte do cabido, como também o contexto administrativo em que desenvolve o seu trabalho. Segue-se a abordagem à utilização dos livros em análise ao longo dos tempos, e que estivaram na base de outros que entretanto foram sendo produzidos (como os Libros de Capellanias) até ao século XVIII pelo menos. O modo como esta transmissão da informação documental se processou fica claramente expresso num esquema com o qual se termina o ponto 2 desta segunda parte da obra. O leitor é assim introduzido no complexo contexto administrativo a que os códices pertenciam, detalhadamente analisado no último capítulo da segunda parte. Depara-se então com aquilo a que o Autor chamou "contexto escriturário" que, juntamente com os capítulos anteriores nos dá a conhecer variados manuscritos elaborados sob a responsabilidade de mayordomos e contadores. Mais do que nunca, Diego Belmonte deixa clara nestes capítulos a relação umbilical entre administração e escrita.

Por tudo o que fica dito, é inquestionável a valia do livro de Diego Belmonte. Sobre o mérito do Autor, pronunciou-se, no tempo e lugar próprios, o júri presente nas suas provas de Doutoramento. Mas uma palavra de felicitação deve ser deixada igualmente à Editorial Universidade de Sevilha por ter publicado o estudo original, dando a conhecer a um público vasto o resultado de uma excepcional investigação que, estou certa, servirá de modelo a outras (nomeadamente em Portugal, onde não existem trabalhos deste género, de dimensão semelhante). Não será menos importante a edição dos dois cartulários que lhe serviram de base: o Libro Blanco e o Libro de Dotaciones. Fica o desafio, na esperança que a EUS o aceite. 